\title{
Penurunan Jumlah Lahan Dan Perubahan Budidaya Tanaman Kopi Bali Kintamani Mengancam Destinasi Wisata Kopi Di Kintamani
}

Ijlal Faiz Bayu Permana a, 1, Made Sukanaa, 2

1ijlalfaiz@gmail.com, 2 madesukana@unud.ac.id

a Program Studi Sarjana Destinasi Pariwisata, Fakultas Pariwisata,Universitas Udayana, Jl. Dr. R. Goris, Denpasar, Bali 80232 Indonesia

\section{Abstract}

This research is conducted in Catur Village, Kintamani District, Bangli Regency. The purpose of this research is to identify the decreasing number of coffee land of Kintamani Bali Coffee plantation and its causes. The data used in this research are qualitative and quantitative, while the data of this research consists of of primary and secondary data. The data is collected through observation, depth interviews, and documentation. The informants are determined through purposive sampling procedure, and they are I Ketut Jati (Head of Masyarakat Perlindungan Indikasi Geografis Kintamani) and Kocong Neca (Local Coffee Farmer). Afterward, the data that has been found is analyzed by descriptive qualitative method.

The results of this research show that the decreasing number of coffee land of Kintamani Bali Coffee plantation on has reach its dangerous point and threaten tourism in Kintamani. In the last two years, the number of coffee land of Kintamani Bali Coffee had decreased significantly from $6.335 \mathrm{Ha}$ to $4.772 \mathrm{Ha}$ and automatically causing the total production of Kintamani Bali Coffee beans dropped from 2.314 Ton to 2.046 Ton. The biggest reason of the decreasing number of coffee land came from land conversion. The difference of income between coffee plantation with orange plantation also made farmers in Desa Catur to shift to grow more orange than coffee. In a 0,5 Ha field, orange plantation could gain profits approximately for Rp 114.945.000, while coffee plantation only gain profits for $R p$ 63.530.000. Moreover, plant-paracitic nematodes are damaging the coffee plantation. Therefore, the number of lands to grow coffee are decreasing.

The recomendation from this research addressed to government service of Agriculture, Plantation and Forestry Bangli to keep oversee Kintamani Bali Coffee plantation and give an aid towards the Nematoda Parasite Diseases problem. Furthermore, farmers required to improve their human resource's skill, so they can use management system on their plantation.

Keywords: Land Degradation of Plantation, Change of Plant Cultivation, Kintamani Bali Coffee, Coffee Tourist Destination, Kintamani District

\section{PENDAHULUAN}

Sektor pariwisata saat ini menjadi salah satu sektor utama dalam perekonomian dan pembangunan di Indonesia. Hal ini dikarenakan pariwisata merupakan salah satu penyumbang devisa terbesar di samping sektor migas. Sektor pariwisata membantu perekonomian masyarakat lokal dan pembangunan sarana/prasarana serta membuka lapangan pekerjaan di daerah tujuan wisata. Selain itu, pariwisata juga memiliki peran dalam pertukaran budaya yang mampu dimanfaatkan sebagai hal yang positif. Oleh karena itu, saat ini pariwisata menjadi sorotan utama bagi pemerintah dalam mendorong perkembangan perekonomian Indonesia.

Dengan terus berkembangnya sektor pariwisata di Indonesia, maka industri pariwisata semakin bertambah dan memiliki jenis yang beragam. Permintaan wisatawan yang terus berubah-ubah memaksa industri pariwisata agar terus berinovasi demi mencapai kepuasan wisatawan. Hal itu yang memicu akan munculnya destinasi-destinasi baru di dalam suatu kawasan pariwisata yang diharapkan mampu memenuhi permintaan wisatawan yang kian berubah-ubah. Salah satu permintaan yang kerap muncul dari wisatawan saat ini yaitu destinasi wisata kopi.

Di Indonesia sendiri, kopi sudah menjadi budaya bagi masyarakatnya sejak masa penjajahan oleh bangsa Belanda hingga sekarang. Sehingga Indonesia memiliki banyak penghasil biji kopi di segala penjuru nusantara, bahkan tidak sedikit yang memiliki kualitas mancanegara. Hal itu didukung dengan tanah Indonesia yang terkenal subur dan iklim tropis yang membuat sangat cocok untuk menaman tanaman kopi. Salah satu provinsi penghasil biji kopi berkualitas di Indonesia yaitu provinsi Bali, tepatnya berada di daerah Kintamani, Kabupaten Bangli yang dikenal dengan sebutan Kopi Bali Kintamani.

Provinsi Bali memiliki beragam daya tarik yang unik yang menjadikannya sebagai destinasi favorit dan memiliki industri pariwisata yang berkembang pesat. Bali juga menjadi pusat pariwisata Indonesia dengan 
bentang alamnya yang kaya, mulai dari pantai hingga dataran tinggi dan pegunungan serta dilengkapi dengan budaya masyarakatnya yang terus terjaga dan menjadi identitas pariwisata Bali. Salah satu dataran tinggi yang ada di Bali yaitu daerah Kintamani di Kabupaten Bangli yang menjadi pusat perkebunan dan penghasil kopi Bali berkualitas. Pertumbuhan perkebunan Kopi Bali kintamani sangatlah penting bagi kelangsungan pariwisata di Bali, karena Kopi Bali kintamani merupakan salah satu komoditas utama dalam permintaan wisatawan yang datang ke Bali, baik domestik maupun mancanegara. Kopi tersebut telah menjadi icon pariwisata Bali dan jenis oleh-oleh yang banyak dicari bagi wisatawan. Dengan potensi yang begitu besar, perkebunan Kopi Bali kintamani telah membuka sektor usaha pariwisata yang berbeda, yaitu agrowisata kopi yang banyak diminati oleh penggemar kopi dari seluruh nusantara dan mancanegara. Sehingga diharapkan Kopi Bali kintamani dapat terus menopang pariwisata Bali dan mampu memenuhi permintaan wisatawan di Bali.

Di samping keunggulan yang telah disebutkan, Kopi Bali Kintamani ternyata memiliki ancaman yang serius dalam waktu jangka panjang, yaitu luas areal tanaman kopi yang semakin menyusut dan jumlah petani kopi yang terus menurun. Hal tersebut memberikan dampak yang buruk kepada permintaan wisatawan secara perlahan. Belum lagi banyak petani kopi yang akhirnya berpindah menjadi petani jeruk karena dirasa lebih menguntungkan. Bila hal ini terus dibiarkan maka potensi pariwisata Kopi Bali Kintamani akan terus merosot dan akhirnya menjadi punah. Oleh karena itu penelitian ini dilakukan untuk mencari tahu dengan jelas penyebab terjadinya ancaman terhadap destinasi wisata Kopi Bali Kintamani dan diharapkan mampu memberikan solusi permasalahan.

\section{KEPUSTAKAAN}

\subsection{Telaah Hasil Penelitian Sebelumnya}

Penelitian mengenai Kopi Bali Kintamani telah dilakukan beberapa kali sebelumnya, sebagian besar penelitian tersebut membahas potensi serta strategi pengembangannya dan belum ada yang membahas secara spesifik tentang ancaman wisata Kopi Bali Kintamani. Sehingga penulis cukup menelaah penelitiaan sebelumnya yang membahas Kopi Bali Kintamani di daerah Kintamani, Bangli.

Di dalam jurnal "Perbandingan Pendapatan antara Usahatani Kopi dan Usahatani Jeruk di Kecamatan Kintamani Kabupaten Bangli" yang ditulis oleh Heryana (2016), terdapat faktor yang mendorong alih fungsi lahan dan alasan-alasan petani yang beralih dari menanam kopi menjadi menanam jeruk. Di jurnal ini juga dijelaskan perbedaan biaya pengeluaran dan pendapatan tanaman kopi dengan tanaman jeruk. Pendapatan usahatani tanaman jeruk lebih tinggi yaitu sebesar Rp 114.945.000 dibandingkan dengan usahatani tanaman kopi hanya $\mathrm{Rp} 63.530 .000$ dengan masing-masing luas 0,50 Ha. Hal inilah yang pada akhirnya meyebabkan petani lebih memilih untuk menanam jeruk dibandingkan kopi.

Lalu dalam jurnal "Analisis Pengembangan Potensi Agrowisata Kopi Luwak di Daerah Kintamani, Bangli" yang ditulis oleh Prabandari (2012), terdapat kesamaan lokasi penelitian dengan yang dilakukan oleh penulis, sehingga dijadikan sebagai acuan dalam penelitian ini. Hanya di dalam penelitian ini memilih spesialitas kopi yang berbeda dengan penulis yaitu Kopi Luwak. Di dalam penelitian tersebut membahas analisis potensi dan beberapa ancaman yang ada di dalamnya. Lalu di dalam jurnal ini secara spesifik menjelaskan analisis kekuatan, kelemahan, peluang, dan ancaman dari Kopi Luwak menggunakan matriks SWOT. Dari analisis tersebut didapatkan hasil bahwa Kopi Luwak memiliki potensi yang tinggi sebagai potensi wisata dan daerah Kintamani sebagai daerah yang tepat sebagai pengembangan agrowisata Kopi Bali Kintamani

\subsection{Landasan Konsep dan Teori Analisis}

Dalam artikel ini menggunakan beberapa konsep diantaranya :

1. Konsep Perkebunan

Menurut Undang-Undang Republik Indonesia Nomor 18 Tahun 2004, yang dimaksud dengan perkebunan adalah "segala kegiatan yang mengusahakan tanaman tertentu pada tanah dan/atau media tumbuh lainnya dalam ekosistem yang sesuai, mengolah dan memasarkan barang dan jasa hasil tanaman tersebut, dengan bantuan ilmu pengetahuan dan teknologi, permodalan serta manajemen untuk mewujudkan kesejahteraan bagi pelaku 
usaha perkebunan dan masyarakat". Perkebunan memberikan manfaat ekonomis dan juga ekologis bagi petani dan juga lingkungan alam di Indonesia. Perkebunan telah menjadi pondasi struktur ekonomis Indonesia sejak lama, bahkan telah ada sejak zaman nenek moyang kita. Sehingga perkebunan juga memiliki nilai sosial budaya yang telah diturunkan dari generasi ke generasi hingga saat ini perkebunan terus menjadi perekat dan pemersatu bangsa.

Tanaman perkebunan merupakan tenaman semusim dan tanaman tahunan, karena jenis dan tujuan pengelolaannya ditetapkan sebagai tanaman perkebunan. Dengan demikian tanaman perkebunan bisa dibedakan menjadi dua, yaitu tanaman semusim dan tanaman tahunan. Tanaman semusim adalah jenis tanaman yang hanya dipanen satu kali dengan siklus hidup satu tahun sekali, contohnya tanaman tebu, kapas dan tembakau. Sementara tanaman tahunan membutuhkan waktu yang panjang untuk berproduksi dan bisa menghasilkan sampai puluhan tahun dan bisa dipanen lebih dari satu kali, misalnya tanaman kelapa sawit, karet, kakao, cengkeh, kopi dan lada.

2. Konsep Alif Fungsi Lahan

Alih fungsi lahan adalah perubahan fungsi sebagian atau seluruh kawasan lahan dari fungsinya semula menjadi fungsi lain yang memiliki dampak negatif terhadap lingkungan atau potensi lahan itu sendiri. Menurut UU No 262007 Tentang Penataan Ruang, alih fungsi lahan adalah "Pemanfaatan ruang mengacu pada fungsi ruang yang ditetapkan dalam rencana tata ruang dilaksanakan dengan mengembangkan penatagunaan tanah, penatagunaan air, penatagunaan udara, dan penatagunaan sumber daya alam lain". Alih fungsi lahan dalam artian perubahan atau penyesuaian peruntukan penggunaan, disebabkan oleh faktor-faktor yang pada umumnya meliputi keperluan untuk memenuhi kebutuhan yang makin bertambah jumlahnya dan meningkatnya tuntutan akan kualitas kehidupan yang lebih baik.

Ada beberapa penyebab terjadinya alih fungsi lahan di antaranya, rendahnya tingkat keuntungan bertani, tidak dipatuhinya peraturan tata ruang (lemahnya penegakkan hukum tentang tata ruang), keinginan mendapatkan keuntungan jangka pendek dari pengalih fungsian lahan, dan rendahnya koordinasi antara lembaga dan departemen terkait dengan perencanaan penggunaan lahan (Agus dkk, 2001). Dalam kaitannya dengan pariwisata Bali, alih fungsi lahan ini terjadi karena tingginya tingkat permintaan terhadap sarana sarana pariwisata. Hal ini juga dipengaruhi oleh bentuk pariwisata yang dikembangkan yaitu pariwisata massal.

\section{Konsep Petani}

Petani adalah jenis pekerjaan yang telah ada sejak zaman peradaban manusia mulai terbentuk. Dengan bertani, manusia mampu bertahan hidup dengan memanfaatkan berbagai macam sayur/buah sebagai konsumsi sehari-hari. Jenis petani sendiri terbagi menjadi beberapa bagian. Secara garis besar terdapat tiga jenis petani, yaitu petani pemilik lahan, petani pemilik yang sekaligus juga menggarap lahan, dan buruh tani. Petani umumnya bertempat tinggal di perdesaan dan sebagian besar di antaranya, tidak sedikit juga yang tinggal di daerah-daerah yang padat penduduk dan hidup di bawah garis kemiskinan.

Di dalam UU No. 19 Tahun 2013 Tentang Perlindungan dan Pemberdayaan Petani yang dimaksud dengan petani dijelaskan dalam Pasal 1 Ayat 3 adalah "warga negara Indonesia perseorangan dan/atau beserta keluarganya yang melakukan usaha tani di bidang tanaman pangan, hortikultura, perkebunan, dan/atau peternakan".

\section{III.METODE PENELITIAN}

Penelitian ini dilakukan di Kintamani Kabupaten Bangli Provinsi Bali. Lokasi ini tepatnya berada di Desa Catur. Metode yang digunakan yaitu analisis deskriptif kualitatif, di mana jenis data yang digunakan adalah data kualitatif. Sumber data yang digunakan yaitu data primer mengenai penyusutan lahan pertanian tanaman kopi di Desa Catur, Kintamani. dan data sekunder yaitu mengenai luas areal tanaman kopi di Kecamatan Kintamani, Jumlah petani kopi, jumlah produksi kopi, dan perbandingan pendapatan petani kopi arabika dan petani jeruk.. Teknik pengumpulan data dilakukan dengan observasi, wawancara, dan dokumentasi. Informan/narasumber yang dipilih adalah ketua I Ketut Jati sebagai ketua organisasi MPIG (Masyarakat Perwakilan Indikasi Geografis) Kintamani dan juga Kocong Neca yang merupakan petani kopi di Desa 
Catur. Teknik analisis data yang digunakan penelitian ini adalah analisis deskriptif kualitatif, yaitu dengan proses mengatur urutan data, mengorganisasikasnnya ke dalam suatu pola, kategori, dan satuan uraian dasar (Moleong, 2000, dalam Utama dan Mahadewi, 2012).

\section{HASIL DAN PEMBAHASAN}

\subsection{Gambaran Umum Paralayang Gunung Banyak}

\subsubsection{Profil Desa Catur}

Desa Catur terletak di sebelah utara Kabupaten Bangli pada ketinggian 1.200 Meter diatas permukaan laut dan memiliki luas wilayah sebesar 746 Ha. Desa Catur memiliki suhu rata-rata harian berkisaran antara 21-30 derajat Celcius. Secara geografis, wilayah Desa Catur berada pada area pegunungan dengan warna tanah ratarata hitam dan umumnya sangat subur. Sehingga sangat cocok digunakan sebagai cocok tanam.

Berdasarkan tata guna tanah, Desa Catur terbagi menjadi: tanah perkebunan dan pertanian (300 $\mathrm{Ha})$, pemukiman/pekarangan (8 Ha), perkantoran (1 ha), sekolah (80 are), pustu (5 are), kuburan (5 Ha), pasar (1Ha), Pura (2 ha), tempat umum lainnya 60 are, hutan negara (60 Ha) dan sisanya adalah tanah yang dipergunakan untuk infrastuktur desa (Data Desa Catur, 2017).

Letak geografis dan kondisi tanah yang subur membuat wilayah Desa Catur sangat cocok dijadikan lahan perkebunan dan holtikultura berbagai jenis sayuran, seperti kol, wortel, bawang prei dan tomat. Namun, komoditas yang paling terkenal di Desa Catur yaitu tanaman jeruk dan kopi, yang mana telah menjadi ikon di desa ini. Jeruk dan kopi arabika merupakan tanaman perkebunan yang paling dominan ditanam diantara jenis tanaman yang lainnya. Maka dari itu, masyarakat Desa Catur menggunakan hasil perkebunan buah jeruk dan hasil olahan kopi sebagai oleh-oleh khas wilayah ini. Perkebunan kopi di Desa Catur telah mendapatkan pengakuan baik nasional dan internasional, salah satunya yaitu telah mengantongi Sertifikat Indikasi Geografis (SGI). Sertifikasi tersebut mampu membawa kopi hasil Desa Catur ke dalam kategori kopi berkualitas.

Desa Catur berada pada jalur pariwisata, yang merupakan jalur konektivitas antar daya tarik wisata (DTW) di Bali antara DTW yang ada di Kabupaten Badung dengan DTW yang ada di kawasan wisata Kintamani. Sehingga desa ini juga menjadi salah satu alternatif bagi wisatawan yang ingin merasakan kehidupan desa yang masih memegang erat budaya nya.

\subsubsection{Kondisi Ekonomi Desa Catur}

Berdasarkan mata pencahariannya, petani merupakan jenis pekerjaan yang paling dominan di Desa Catur, yaitu sebanyak 934 jiwa. Selanjutnya terdapat ibu rumah tangga sebagai jenis pekerjaan terbanayak kedua setelah petani yaitu sebanyak 425 jiwa. Kemudian terdapat pelajar/mahasiswa sebagai jenis pekerjaan terbanyak ketiga yaitu sebanyak 400 jiwa.

Sebagaian besar lahan yang ada di Desa Catur dimanfaatkan sebagai lahan pertanian. Tanaman yang dibudidayakan yaitu tanaman buah (kopi arabika dan jeruk), tanaman holtikultura (tomat, bawang, kol) tanaman pangan (jagung, ketela pohon, talas).

Hingga saat ini hal yang terus dikembangkan di Desa Catur sebagai salah satu pendapatan utama bagi petani disana, antara lain adalah sektor perkebunan dengan kopi arabika dan jeruk, sedangkan untuk mendukung peningkatan hasil usaha dibidang pertanian dan usaha penyelamatan lingkungan di masing-masing banjar dinas di Desa Catur sudah ada subak-subak abian.

\subsubsection{Demografis Desa Catur}

Desa Catur merupakan desa yang memiliki jumlah penduduk sebesar 2.005 jiwa. Dari kesemuanya tersebar di masingmasing dusun yang ada di Desa Catur yakni Dusun Catur, Dusun Lampu dan Dusun Mungsengan (Data BPS Kab. Bangli, 2017). Desa Catur juga memiliki sebuah pasar tradisional yang terdapat di wilayah Dusun Lampu, maka dari itu tidak sedikit penduduk yang bekerja sebagai pedagang dengan banyak yaitu 53 jiwa. Setelah itu terdapat pegawai swasta sebanyak 67 jiwa, pensiunan sebanyak 32 jiwa, sebagai dosen sebanyak 1 jiwa, sebagai TNI (Tentara Nasional Indonesia) sebanyak 6 jiwa, sebagai buruh tani /buruh harian lepas sebanyak 75 jiwa 
dan sebagai PNS (Pegawai Negeri Sipil) sebanyak 12 jiwa (Data BPS Kab. Bangli, 2017).

\subsection{Penurunan Jumlah Lahan Perkebunan Kopi Kintamani Bali}

Pertumbuhan perkebunan Kopi Kintamani Bali kian mengalami penurunan dan isu-isu pun terus terdengar akan terancamnya perkebunan Kopi Kintamani Bali, salah satunya yang terjadi di Desa Catur

Contohnya petani kopi dan pelaku usaha di Desa Catur yang mengkhawatirkan bila hal ini terus dibiarkan maka lahan perekebunan kopi akan semakin berkurang dan pada akhirnya semua lahan perkebunan kopi beralih fungsi menjadi fungsi-fungsi lainnya tergantung kebutuhan masyarakat disana. Bahkan hal ini juga membuat resah pariwisata Bali, karena dirasa Kopi Kintamani Bali merupakan sebuah potensi pariwisata dan telah menjadi permintaan sebagian besar wisatawan yang berkunjung ke Bali, khususnya para penggemar kopi dari seluruh nusantara dan mancanegara yang telah mengakui bahwa Kopi Kintamani Bali salah satu kopi yang memiliki cita rasa unik.
Dari Tabel 1 dapat dilihat bahwa pada dua tahun terakhir telah mengalami penurunan luas areal tanaman dan juga jumlah produksi Kopi Kintamani Bali yang cukup signifikan. Hingga tahun 2016 telah mengalami penurunan areal tanaman kopi $24,7 \%$ yaitu seluas $1563 \mathrm{Ha}$ dan juga penurunan jumlah produksi $11,6 \%$ yaitu sebanyak 268,39 Ton. Hal ini merupakan masalah yang serius terutama bagi petani kopi yang hanya memiliki perkebunan skala kecil. Dampak ekonomi akan jelas terlihat dengan adanya penurunan tersebut dan banyak yang mencoba beralih untuk menanam tanaman lain yang dirasa lebih menjanjikan. Sehingga seperti yang bisa dilihat di tabel 1 sejak dua tahun terakhir terus terjadi penurunan jumlah petani kopi dan hal ini tentu saja memiliki penyebabpenyebab tertentu yang membutuhkan penelitian lebih lanjut untuk mengetahuinya. Dengan adanya penurunan lahan perkebunan Kopi Kintamani Bali di Kecamatan Kintamani berdasarkan tabel diatas, maka hal ini akan berdampak besar bagi pariwisata di Bali. 
memang banyak bermunculan di Kecamatan Kintamani. Oleh karena itu pertumbuhan perkebunan Kopi Kintamani Bali, yang persentase nya telah turun sekitar $11,5 \%$ dari tahun 2014 ke tahun 2016, harus dijaga jangan sampai terus mengalami penurunan dan terancam punah, yang pada akhirnya akan merugikan para petani dan juga pariwisata Bali.

4.3. Penyebab Terjadinya Penurunan Jumlah Lahan Perkebunan Kopi Kintamani Bali

\subsubsection{Alih Fungsi Lahan}

Alih fungsi lahan merupakan penyebab terbesar terjadinya penurunan luas areal perkebunan Kopi Kintamani Bali di Desa Catur. Menurut UU No 262007 Tentang Penataan Ruang, "alih fungsi lahan adalah Pemanfaatan ruang mengacu pada fungsi ruang yang ditetapkan dalam rencana tata ruang dilaksanakan dengan mengembangkan penatagunaan tanah, penatagunaan air, penatagunaan udara, dan penatagunaan sumber daya alam lain". Petani berbondong-

bond

Tabel 1

Data Banyaknya Petani, Luas Areal dan Produksi Tanaman Kopi Di

ong Kintamani 2010-2016

\begin{tabular}{|c|c|c|c|c|}
\hline \multirow{7}{*}{$\begin{array}{l}\text { Kare } \\
\text { na } \\
\text { diras } \\
\text { a } \\
\text { Kopi } \\
\text { Kinta } \\
\text { mani } \\
\text { Bali } \\
\text { meru } \\
\text { paka }\end{array}$} & Tahun & $\begin{array}{c}\text { Jumlah Petani } \\
\text { (Orang) }\end{array}$ & $\begin{array}{c}\text { Luas Areal } \\
\text { Tanaman (Ha) }\end{array}$ & $\begin{array}{c}\text { Jumlah Produksi } \\
\text { (Ton) }\end{array}$ \\
\hline & 2010 & 6.430 & 3.752 & $1.703,46$ \\
\hline & 2011 & 6.420 & 3.775 & $1.756,26$ \\
\hline & 2012 & 7.143 & 4.503 & 2.008 \\
\hline & 2013 & 7.392 & 5.346 & $2.353,28$ \\
\hline & 2014 & 7.291 & 6.335 & $2.314,39$ \\
\hline & 2015 & 1.774 & 5.918 & $2.165,23$ \\
\hline & 2016 & 1.634 & 4.772 & 2.046 \\
\hline
\end{tabular}

Sumber: Dinas Pertanian Perkebunan dan Perhutanan Bangli, 2017 sedikit tanaman kopi yang

n sebuah potensi pariwisata dan telah menjadi permintaan sebagian besar wisatawan yang berkunjung ke Bali, khususnya para penggemar kopi dari seluruh nusantara dan mancanegara yang telah mengakui bahwa Kopi Kintamani Bali

salah satu kopi yang memiliki cita rasa unik. Kopi Kintamani Bali juga telah membuka peluang bagi jenis pariwisata yang berbeda di Bali, yaitu agrowisata Kopi Kintamani Bali yang masih bertahan dan itupun menurut petani tidak memiliki kualitas sebagus seperti sediakala.

Menurut petani kopi bernama Kocong Neca, Tren ini diyakini bermula karena :

"Diawali dengan pembelian lahan yang dilakukan di Desa Catur oleh petani dari desa sebelah untuk menanam jeruk, hal ini pada akhirnya mendapat perhatian petani-petani 
kopi di Desa Catur setelah mengetahui penghasilan yang didapat sangat tinggi dibandingkan menanam kopi, yang pada akhirnya membuat banyak petani kopi ikutikutan mencoba menanam jeruk" (Wawancara dengan Kocong Neca (Petani Kopi Desa Catur, 2017)

Namun kenyataannya untuk mendapatkan hasil yang banyak dari menanam jeruk membutuhkan pula modal yang banyak, yang dimana tidak disadari sejak awal oleh petani-petani yang termakan tren tersebut dan tidak sedikit petani yang hanya memiliki modal pas-pasan mencoba mengikuti tren ini. Hal ini terjadi menurut I Ketut Jati (Ketua MPIG Kintamani) karena:

"Kualitas SDM yang dimiliki oleh perkebunan kopi dinilai rendah, sehingga mereka tidak menggunakan ilmu manajemen dalam memperhitungkan biaya-biaya yang diperlukan terlebih dahulu untuk menanam jeruk dan juga hal ini membuat petani cepat berubah pikiran untuk berganti menanam tanaman yang dirasa sedang naik harganya" (I Ketut Jati, Ketua MPIG Kintamani)

Namun bagi petani yang memiliki modal besar tentu saja mereka telah sukses mendapatkan penghasilan yang besar dari menanam jeruk dan pada akhirnya mereka mengganti seluruh perkebunan kopi nya dengan menanam jeruk. Hingga sekarang trend ini masih berlanjut walaupun beberapa petani mulai menyadari bahwa menanam kopi sebenarnya lebih menjanjikan.

Sedangkan menanam kopi hanya memerlukan setengah biaya dari jeruk dan tidak memerlukan perawatan khusus seperti menyemprot obat-obatan. Tetapi tetap saja petani menemukan kendala-kendala dalam menanam kopi. tanaman kopi memerlukan tanaman perindang yang ditanam bersebelahan agar rimbun, bila kurang rimbun akan memepengaruhi hasil panen kopi Sehingga jika petani ingin menanam kopi harus menanam tanaman perindang dahulu dan membuat petani sering berganti-ganti tanaman. Terlebih lagi jika petani hanya menanam kopi harus menunggu kurang lebih 4 tahun untuk mendapatkan hasil panen, hal itu tidak memberikan pilihan kepada petani untuk menanam tanaman lain agar mendapatkan hasil yang cepat seperti umbiumbian dan sayur-sayuran yang rata-rata dalam hitungan bulanan dapat dipanen sehingga menggunakan sistem tumpang sari.

\subsubsection{Perbandingan Pendapatan Petani Kopi dengan Jeruk}

Perbedaan jumlah pendapatan tentu saja mempengaruhi petani untuk berganti dari menanam kopi, maka diperlukannya perbandingan pendapatan petani kopi dengan jeruk. Untuk mengetahui perbandingan biaya pendapatan petani dari membudidayakan tanaman kopi dan tanaman jeruk, yaitu dengan menggunakan analisis pendapatan Rumus analisis pendapatan kopi dan tanaman jeruk diperoleh dari total revenue (total penerimaan) - total cost (total biaya), sehingga dapat dilihat seberapa besar pendapatan usahatani dan produksi yang dihasilkan petani (Budiono, 2002). Pendapatan budidaya tanaman jeruk lebih tinggi yaitu Rp. 134.945 .000 per 50 are, dibandingkan dengan tanaman kopi yaitu Rp. 56.780 .000 per 50 are. Hasil pendapatan tersebut merupakan faktor petani beralih untuk membudidayakan tanaman jeruk daripada tanaman kopi karena pendapatan tanaman jeruk lebih tinggi.

Tanaman jeruk membutuhkan biaya pemeliharaan yang lebih tinggi, yaitu sebesar Rp 25.055.000 dibandingkan dengan tanaman kopi arabika yang sebesar Rp 15.220.000. Tanaman jeruk juga memiliki pendapatan lebih tinggi, yaitu sebesar Rp 134.945.000 dibandingkan tanaman kopi arabika yang sebesar Rp 56.780.000. Hal ini lah yang melatar belakangi para petani Kopi Kintamani Bali mulai beralih untuk menanam jeruk karena dirasa mampu menghasilkan banyak keuntungan dalam sekali panen. Padahal perlu digarisbawahi untuk menanam jeruk memerlukan jumlah modal yang besar agar mendapatkan hasil yang besar juga, sehingga bagi petani yang mulai mengikuti tren ini tanpa mempersiapkan modal yang besar hanya akan mendapatkan hasil yang kurang mencukupi atau bahkan gagal panen dan hal ini lah yang banyak terjadi di Kintamani, petani cenderung hanya mengikuti tren harga 
komoditas yang sedang naik tanpa berpikir panjang dan melakukan perhitungan

Sehingga lahan perkebunan Kopi Kintamani Bali perlahan akan terus menurun dan akan sangat merugikan bagi petani apabila hal ini terus dibiarkan. Hal ini juga akan mengancam pariwisata Bali bila lahan perkebunan tanaman Kopi Kintamani Bali terus mengalami penurunan dan akhirnya tidak mampu lagi memenuhi permintaan dari wisatawan.

\subsubsection{Kerentanan Tanaman Terserang Penyakit Parasit Nematoda}

Penyakit parasit Nematoda merupakan penyebab petani kopi di Desa Catur sering mengalamai gagal panen. Penyakit Nematoda mengakibatkan petani harus berganti-ganti tanaman dan akhirnya kesuburan lahan pun terus berkurang. Hal ini yang mengakibatkan terus berkurangnya lahan perkebunan kopi karena rentan terserang penyakit parasit Nematoda.

Hingga saat ini petani di Desa Catur belum menemukan cara untuk menyembuhkan tanaman yang terserang oleh penyakit ini dan dikhawatirkan akan terus menggerogoti seluruh perkebunan kopi yang ada di Desa Catur. Hal ini tentu merugikan petani karena mereka perlu mengganti tanaman yang sudah terkena penyakit sesegera mungkin dan pada akhirnya mereka mengalami kerugian. Belum ada peran pemerintah akan penyakit parasit Nematoda dengan memberikan bantuan ataupun melakukan penanganan. Sehingga petani sedang mencari akal untuk menyiasati hal ini dengan tidak menggunakan terasering karena akan membuat air tergenang dan mudah tersrang penyakit.

\section{IV.PENUTUP}

\subsection{Simpulan}

Penurunan lahan perkebunan Kopi Kintamani Bali sudah mencapai titik yang mengkhawatirkan dan dapat mengancam pariwisata di Bali. Hal ini ditinjau dari aspek yang sudah dipaparkan oleh penulis, yaitu:

1. Pada dua tahun 2014 hingga 2016 perkebunan Kopi Kintmani Bali di Kecamatan Bali telah mengalami penurunan luas areal tanaman dan jumlah produksi Kopi Kintamani Bali yang cukup signifikan. Hingga tahun 2016 telah mengalami penurunan areal tanaman kopi seluas 1563 Ha dan juga penurunan jumlah produksi sebanyak 268,39 Ton. Hal ini merupakan masalah yang serius terutama bagi petani kopi yang hanya memiliki perkebunan skala kecil. Dampak ekonomi akan jelas terlihat dengan adanya penurunan tersebut dan banyak yang mencoba beralih untuk menanam tanaman lain yang dirasa lebih menjanjikan.

2. Penurunan lahan perekebunan Kopi Kintamani Bali sebagian besar disebabkkan oleh alih fungsi lahan, yaitu beralih fungsi menjadi tanaman jeruk. Hal ini dilatar belakangi petani-petani yang termakan trend menanam jeruk dan tidak sedikit petani yang hanya memiliki modal pas-pasan mencoba mengikuti trend ini Hal ini didasari karena SDM yang dimiliki oleh para petani dinilai rendah, sehingga mereka tidak menggunakan ilmu manajemen dalam memperhitungkan biaya-biaya yang diperlukan terlebih dahulu untuk menanam jeruk

3. Perbedaan jumlah pendapatan mempengaruhi petani untuk berganti dari menanam kopi menjadi menanam jeruk. Pendapatan budidaya tanaman jeruk lebih tinggi yaitu Rp. 134.945 .000 per 50 are, dibandingkan dengan tanaman kopi yaitu Rp. 56.780.000 per 50 are. Hasil pendapatan tersebut merupakan faktor petani beralih untuk membudidayakan tanaman jeruk daripada tanaman kopi karena pendapatan tanaman jeruk lebih tinggi.

4. Penyakit parasit Nematoda juga merupakan penyebab penurunan lahan perkebunan Kopi Kintamani Bali karena memberi dampak kepada petani kopi di Desa Catur sering mengalamai gagal panen. Parasit Nematoda yang menyerang pada tanaman kopi seringkali berasal dari spesies Pratylenchus coffeae dan Radopholus similis. Keduanya merupakan nematoda yang menyerang jaringan akar tumbuhan kopi. Hal ini yang mengakibatkan terus berkurangnya lahan perkebunan kopi karena rentan terserang penyakit parasit Nematoda. Hingga saat ini petani di Desa Catur belum menemukan cara untuk menyembuhkan tanaman yang terserang oleh penyakit ini dan dikhawatirkan akan terus menggerogoti 
seluruh perkebunan kopi yang ada di Desa Catur. Hal ini tentu merugikan petani karena mereka perlu mengganti tanaman yang sudah terkena penyakit sesegera mungkin dan pada akhirnya mereka mengalami kerugian.

\subsection{Saran}

Dari pembahasan sebelumnya adapun saran yang dapat diberikan adalah :

1. Dinas Pertanian Perkebunan dan Perhutanan Bangli diharapkan terus memonitor jumlah lahan perkebunan Kopi Kintamani Bali di Kecamatan Kintamani dan berkordinasi dengan petani untuk menghindari adanya penurunan secara terus-menerus. Selain itu diharapkan untuk menangani permasalahan penyakit parasit Nematoda serta memberikan bantuan obat bagi perkebunan Kopi Kintamani Bali di Kecamatan Kintamani agar terhindar dari gagal panen.

2. Diperlukannya peningkatan kapasitas SDM bagi petani kopi di Kecamatan Kintamani Bali sehingga mampu menggunakan ilmu manajemen dalam menanam tanaman dan akan tersadar bahwa menanam tanaman kopi lebih menjanjikan dan hanya membutuhkan modal lebih sedikit dari jeruk. Sehingga alih fungsi lahan dari kopi ke jeruk akan berkurang.

3. Diharapkan petani tidak mudah tergiur dengan hasil yang besar dari tanaman jeruk karena membutuhkan modal dua kali lipat dari perkebunan kopi terutama bagi petani bermodal kecil.

\section{DAFTAR PUSTAKA}

Amdani, S. 2008. Analisis Potensi Obyek Wisata Alam Pantai di Kabupaten Gunungkidul. Universitas Muhammadiyah Surakarta.

Budiono, 2002. Pengantar Ilmu Ekonomi, No.1 (Ekonomi Mikro). BPFE, Yogyakarta.

Heryana, I Putu Ajus. 2016. Perbandingan Pendapatan antara Usahatani Kopi dan Usahatani Jeruk di Kecamatan Kintamani Kabupaten Bangli. Jurnal: Fakultas Pertanian, Universitas Udayana.

Moleong. 2010. Metodologi Penelitian Kualitatif. Bandung: Remaja Rosdakarya.

Prabandari, Wijayanti Dewi. 2012. Analisis Pengembangan Potensi Agrowisata Kopi Luwak di Daerah Kintamani, Bangli, Bali. Jurnal: Sekolah Tinggi Pariwisata Trisakti.

Sudiarta, Made. 2006. Ekowisata Hutan Mangrove Wahana Pelestarian Alam Dan Pendidikan Lingkungan. Jurnal: Politeknik Negeri Bali.

Undang-Undang Republik Indonesia Nomor 18 Tahun 2004 Tentang Perkebunan.

Undang-Undang Republik Indonesia Nomor 26 Tahun 2007 Tentang Penataan Ruang.

Undang-Undang Republik Indonesia Nomor 10 Tahun 2009 Tentang Kepariwisataan.

Undang-Undang Republik Indonesia Nomor 19 Tahun 2013 Tentang Perlindungan dan Pemberdayaan Petani.

Utama, Rai dan Eka, Mahadewi. 2012. Metodologi Penelitian Pariwisata dan Perhotelan. Yogyakarta: Andi Offset.

SUMBER LAIN :

https://banglikab.bps.go.id/ (diakses pada tanggal 7 Maret 2017 Pukul 15.25)

http://www.cikopi.com/2010/08/agrowisata-kopi-dibali/ (diakses pada tanggal 16 Maret 2017 Pukul 19.30)

http://lembahilmu.com/kopi-bali-kintamani/ (diakses pada tanggal 16 maret 2017 Pukul 20.00)

https://bbppketindan.bppsdmp.pertanian.go.id/blog/sert ifikasi-indikator-geografis-kopi-kintamani-sebagaiupaya-peningkatan-daya-saing-dan (diakses pada tanggal 22 July 2019 Pukul 18.00) 